\section{A NEW ANTIFUNGAL SUBSTANCE, BROMOMONILICIN, AND ITS PRECURSOR PRODUCED BY MONILINIA FRUCTICOLA}

Sir :

In a previous paper ${ }^{1)}$ we reported the structural elucidation of a new antifungal metabolite, chloromonilicin (1), isolated as a growth selfinhibitor of phytopathogenic fungi Monilinia fructicola. It contained a novel seven-membered lactone ring presumably formed by oxidative cleavage of a benzene nucleus in a xanthone system. Subsequently we have isolated a new chlorine containing metabolite, chloropinselin (2), a probable precursor of $\mathbf{1}$. Also, bromomonilicin (3) and bromopinselin (4) were prepared for activity and biosynthetic studies. Biosynthetic incorporation of $\mathbf{4}$ into 3 was accomplished using $M$. fructicola culture.

During the course of isolation of $\mathbf{1}$, a new product $\mathrm{C}_{18} \mathrm{H}_{11} \mathrm{O}_{8} \mathrm{Cl}$ was isolated from the culture filtrate as yellow needles (2: mp 246 $247.5^{\circ} \mathrm{C}$; IR $\nu_{\mathrm{max}}^{\mathrm{KBr}} \mathrm{cm}^{-1} 3315,1715,1650,1621$, $1582,1500)$. Its ${ }^{1} \mathrm{H}$ NMR $\left(\delta\right.$, acetone- $\left.d_{6}\right)$ spectrum showed the presence of a $C$-methyl group (2.43 (br s) ppm), an $O$-methyl group (3.90 (s) $\mathrm{ppm})$, a pair of aromatic meta-coupling protons $(6.66(\mathrm{~m})$ and $6.91(\mathrm{~m}) \mathrm{ppm}, J=c a .2 \mathrm{~Hz})$, an isolated aromatic proton $(7.61(1 \mathrm{H}, \mathrm{s}) \mathrm{ppm})$ and two chelated phenolic hydroxyl groups $(8 \sim 9$ (br) and $12.0(\mathrm{~s}) \mathrm{ppm})$. The UV spectrum of 2 $\left(\lambda_{\max }^{\mathrm{M} \text { oㅐ }} \mathrm{nm}(\varepsilon) 237(37,000), 263(45,000), 294\right.$ $(13,000), 324$ (sh, 5,700), and $386(8,700))$ was superimposable on that of sydowinin $\mathrm{B}^{2)}$ (methyl 2,8-dihydroxy-6-hydroxymethylxanthone-1-carboxylate), suggesting the presence of a 2,8-dihydroxyxanthone-1-carboxylate structure in $\mathbf{2}$. By catalytic hydrogenation over palladium on charcoal in a $10 \%$ methanolic potassium hydroxide solution, 2 gave a dechlorinated product: mp $222.5 \sim 223.0^{\circ} \mathrm{C}$; MS $m / z 300\left(\mathrm{M}^{+}\right)$, whose ${ }^{1} \mathrm{H}$ NMR spectrum $\left(360 \mathrm{MHz}, \mathrm{CDCl}_{3}\right)$ showed characteristic signals of aromatic ortho-coupling protons at $\delta 7.36$ and $7.48(\mathrm{ABq}, J=9 \mathrm{~Hz}) \mathrm{ppm}$. The product was identified with pinselin (5) by comparison of UV and IR spectra $^{3 \sim 5)}$ and melting point ${ }^{6)}$. The position of chlorine atom in 2 was determined by the nuclear Overhauser effect (NOE) experiment on the dimethyl ether of 2. Irradiation of the methoxyl signal at $\delta 3.88 \mathrm{ppm}$ increased the intensity of the signal of an aromatic one-proton singlet at $\delta 7.36 \mathrm{ppm}$ (increment: $21 \%$ ). Thus, the structure of 2 was assigned to 4-chloropinselin. 2 showed no antifungal and antibacterial activities.

A new compound considered promising as an antifungal substance, bromomonilicin (3), was prepared by fermentation and was identified, as in the following. The spore suspension of $M$. fructicola was inoculated into $100 \mathrm{ml}$ culture medium containing sucrose (commercial) $2 \%$, malt extract $2 \%$ and sodium bromide $0.1 \%$ in 500 -ml Sakaguchi flask and the flasks were incubated at $24^{\circ} \mathrm{C}$ for 12 days on a reciprocal shaker. Combined ethyl acetate extracts of the culture filtrate were chromatographed over Silica gel BW-820 with benzene - EtOAc to give fractions 2 and 4 . Rechromatography of the fraction 2 over Silica gel CQ-3 and its purification by HPLC (SIL-CN, n-hexane - THF $\mathrm{AcOH}(5: 1: 0.03))$ and preparative TLC (Kieselgel, benzene-EtOAc (20:1)) afforded bromomonilicin as yellow needles: $\mathrm{mp}$ 183 $183.5^{\circ} \mathrm{C} ;[\alpha]_{\mathrm{D}}^{20}+170^{\circ}\left(\mathrm{CHCl}_{3}\right)$; MS $m / z 394$ and $396\left(1: 1, \mathrm{M}^{+}\right)$; IR $\nu_{\max }^{\mathrm{KBr}} \mathrm{cm}^{-1} 3430,3052,1739$, $1725,1650,1612,1586$; UV $\lambda_{\max }^{\mathrm{MeOH}} \mathrm{nm}(\varepsilon) 279$ $(39,000) ;{ }^{1} \mathrm{H}$ NMR $\left(\mathrm{CDCl}_{3}\right) \delta 12.08(1 \mathrm{H}$, br s,

Fig. 1. Structures of halomonilicins (1 and 3), halopinselins (2, 4 and $\mathbf{6})$, pinselin (5) and the keto-form of 4-bromopinselin (7).<smiles>[R]C1=CC(=O)OC(C(C)=O)C1=C1Oc2cc(C)cc(O)c2C1=O</smiles>

$1 \mathrm{R}=\mathrm{Cl}$

$3 \mathrm{R}=\mathrm{Br}$<smiles>CCCCc1c(O)cc(O)c(C(=O)O)c1C(=O)O</smiles>

$2 \mathrm{R}=\mathrm{Cl} \mathrm{R}^{\prime}=\mathrm{H}$

$4 \mathrm{R}=\mathrm{Br} \quad \mathrm{R}^{\prime}=\mathrm{H}$

$5 \quad \mathrm{R}=\mathrm{H} \quad \mathrm{R}^{\prime}=\mathrm{H}$

$6 \mathrm{R}=\mathrm{R}^{\prime}=\mathrm{Br}$<smiles>CC(=O)C1C(=O)C=C(Br)c2oc3cc(C)cc(O)c3c(=O)c21</smiles>

7 
Table 1. Antimicrobial spectrum of bromomonilicin (3).

\begin{tabular}{lc}
\hline \multicolumn{1}{c}{ Test organism } & MIC $(\mu \mathrm{g} / \mathrm{ml})$ \\
\hline Staphylococcus aureus 209P & $>50$ \\
Escherichia coli NIHJ & $>50$ \\
Shigella flexneri IID642 & $>50$ \\
Pseudomonas aeruginosa 1001 & $>50$ \\
Candida albicans YU 1200 & 25 \\
Trichophyton asteroides & 6.2 \\
T. interdigitale & 6.2 \\
T. rubrum IFO 5467 & 6.2 \\
\hline
\end{tabular}

Agar dilution method on glucose nutrient agar.

$\mathrm{OH}), 7.13(1 \mathrm{H}, \mathrm{s}), 6.83(1 \mathrm{H}, \mathrm{m}), 6.73(1 \mathrm{H}, \mathrm{m})$, $6.41(1 \mathrm{H}$, br s), $3.79(3 \mathrm{H}, \mathrm{s}), 2.42(3 \mathrm{H}$, br s). Its structure (3) was confirmed by alkaline methanolysis. The methanolysis product ( $\mathrm{mp}$ $195.5 \sim 197.5^{\circ} \mathrm{C}$ ) was identical in all respects (UV, IR and MS) with that derived from chloromonilicin $^{1)}$. Bromomonilicin (3) showed expected antifungal activity against Candida and Trichophyton sp. (Table 1), but the activity was about one-fourth of that of $\mathbf{1}$.

The fraction 4 was rechromatographed over Silica gel CQ-3 to give crude yellow crystals of 4-bromopinselin, which were crystallized from acetonitrile and were purified by HPLC (ODS, $\mathrm{H}_{2} \mathrm{O}$ - acetonitrile (1:1)). 4-Bromopinselin showed: $\mathrm{mp} 223.5 \sim 224.0^{\circ} \mathrm{C}$; MS $\mathrm{m} / \mathrm{z} 378$ and $380\left(1: 1, \mathrm{M}^{+}\right)$; UV $\lambda_{\max }^{\mathrm{MeOH}} \mathrm{nm}(\varepsilon) 238(26,000)$, 263 (31,500), 292 (11,000), 324 (sh, 5,400), 385 $(6,400)$; ${ }^{1} \mathrm{H}$ NMR (acetone- $\left.d_{6}\right) \delta 12.3(1 \mathrm{H}, \mathrm{s}$, $\mathrm{OH}), 7.79(1 \mathrm{H}, \mathrm{s}), 6.90(1 \mathrm{H}, \mathrm{m}), 6.68(1 \mathrm{H}, \mathrm{m})$, $3.92(3 \mathrm{H}, \mathrm{s}), 2.43(1 \mathrm{H}, \mathrm{br} \mathrm{s})$. From these spectral data, its structure was assigned to 4-bromopinselin (4). The position of bromine atom was confirmed by the NOE experiment on the dimethyl ether of 4 ; a NOE was observed between a methoxyl signal at $\delta 3.85 \mathrm{ppm}$ and an aromatic one-proton singlet at $\delta 7.52 \mathrm{ppm}$. In addition, a very minor metabolite 6: $\mathrm{mp} \mathrm{ca} .340^{\circ} \mathrm{C}$, MS $m / z 456,458,460\left(1: 2: 1, \mathbf{M}^{+}\right)$, was isolated from the 4-bromopinselin fraction by preparative TLC (Silica gel $\mathrm{GF}_{254}$, benzene-EtOAc (5:1), multiple developments ( 7 times)), and was identified to be 4,5-dibromopinselin on the basis of spectral data of its dimethyl ether: $\mathrm{mp} 243 \sim 245^{\circ} \mathrm{C}$; MS $m / z$ 484, 486, $488\left(1: 2: 1, \mathrm{M}^{+}\right)$; IR $\nu_{\max }^{\mathrm{KBr}}$ $\mathrm{cm}^{-1} 1730,1661$; UV $\lambda_{\max }^{\mathrm{MeOH}} \mathrm{nm}(\varepsilon) 243(36,400)$, 254 (sh, 35,900), 293 (7,800), 319 (6,300), 373 $(9,200) ;{ }^{1} \mathrm{H}$ NMR $\left(\mathrm{CDCl}_{3}\right) \delta 7.58(3-\mathrm{H}), 6.73$ $(7-\mathrm{H}), 4.04\left(\mathrm{COOCH}_{3}\right), 3.97\left(2-\mathrm{OCH}_{3}\right), 3.89$
$\left(8-\mathrm{OCH}_{3}\right), 2.57\left(6-\mathrm{CH}_{3}\right)$. (A NOE was observed between 2- $\mathrm{OCH}_{3}$ and $3-\mathrm{H}$, and $8-\mathrm{OCH}_{3}$ and 7-H).

The incorporation of 4-bromopinselin (4), as biosynthetic precursor, into bromomonilicin (3) was performed as described below. $M$. fructicola was cultured in a $500-\mathrm{ml}$ Sakaguchi flask containing $100 \mathrm{ml}$ of a medium consisting of malt extract $1 \%$ and sucrose (commercial) $2 \% .4(1.5 \mathrm{mg}$ in $0.06 \%$ sodium carbonate solution $(0.2 \mathrm{ml})$ ) was added to the fermentation broth $(100 \mathrm{ml}) 10$ days after inoculation. After an additional 4 days the broth $(\mathrm{pH} 4.4)$ was filtered and extracted with EtOAc. The chloroand bromomonilicin fraction prepared from the extract by preparative TLC was subjected to mass spectrometric analysis. The molecular ions $\mathrm{m} / \mathrm{z}$ 394 and 396, and fragment ions $m / z 307$ and 309 $\left(\mathrm{M}^{+}-\mathrm{COOCH}_{3}-\mathrm{CO}\right)$ formed from 3 were all clearly detected in the mass spectrum of chloromonilicin, suggesting that bromomonilicin is generated by selective oxidative cleavage of one of the benzene nuclei in 4-bromopinselin. Addition of 6 as a control experiment did not give substantially the molecular and fragment ions of 3 in the mass spectral analysis. HPLC analysis showed that 3 was incorporated to the extent of $4 \%$. To the best of our knowledge, this is the first instance of Baeyer-Villiger type cleavage of phenolic metabolites ${ }^{7)}$, which are oxidized via the corresponding keto-form 7.

\section{Acknowledgments}

The authors thank Professor T. HAMASAKI, Tottori University, for the generous gift of the authentic sample of sydowinin B, Mr. N. Sugimoto, senior student, for his help in this study, and Dr. K. TsuJI, the Institute of Physical and Chemical Research, for his advice in manuscript preparation. This work was supported in part by a Grant-in-Aid for Scientific Research from the Ministry of Education, Science and Culture of Japan.

\section{HIDEAKI KaCHI HIROYUKI HATTORI ${ }^{\dagger}$ TAKESHI SASSA}

Department of Agricultural Chemistry, Yamagata University, Tsuruoka, Yamagata 997, Japan

${ }^{\dagger}$ Analytical Center, National Institute for Basic Biology, Okazaki, Aichi 444, Japan

(Received June 22, 1985) 


\section{References}

1) SASSA, T.; H. KaChI, M. Nukina \& Y. SuzuKi: Chloromonilicin, a new antifungal metabolite produced by Monilinia fructicola. J. Antibiotics 38: 439 441, 1985

2) Hamasaki, T.; Y. Sato \& Y. Hatsuda: Structure of sydowinin A, sydowinin B, and sydowinol, metabolites from Aspergillus sydowi. Agric. Biol. Chem. 39: 2341 2345, 1975

3) Ginde, B. S.; B. D. Hosangadi, N. A. Kudav \& A. B. KulKarni: Chemical investigations on Cassia occidentalis Linn. 1. Isolation and structure of cassiollin, a new xanthone. J.
Chem. Soc. (C) 1970: 1285 1289, 1970

4) Moppett, C. E.: Revised structure for cassiollin: Identity with pinselin. J. Chem. Soc. Chem. Commun. 1971: 423 424, 1971

5) Yamazaki, M. \& E. OKuyama: Isolation and structures of oxaphenalenone dimers from Talaromyces bacillosporus. Chem. Pharm. Bull. 28: 3649 3655, 1980

6) Munekata, H.: Studies on some new metabolic products of Penicillium. II. J. Biochem. (Japan) 40: 451 460, 1953

7) Manitto, P.: Biosynthesis of Natural Products. pp. 186 191, Halsted Press, New York, 1981 